\title{
Caryocar coriaceum (Caryocaraceae) diaspore removal and dispersal distance on the margin and in the interior of a Cerrado area in Northeastern Brazil
}

\author{
Gilney Charll dos Santos ${ }^{1,2}$, Nicola Schiel ${ }^{2}$, Elcida de Lima Araújo² \& \\ Ulysses Paulino Albuquerque ${ }^{2}$ \\ 1. Piauí Federal Institute-IFPI, Education Department, 64770-000, Primavera, São Raimundo Nonato, Piauí, Brazil; \\ gilneycharll@hotmail.com \\ 2. Pernambuco Rural Federal University-UFRPE, Biology Department, Postgraduate Program in Ethnobiology and \\ Nature Conservation, 52171-900, Dois Irmãos, Recife, Pernambuco, Brazil; nschiel@yahoo.com, \\ elcida@db.ufrpe.br, upa@db.ufrpe.br
}

Received 26-VIII-2015. Corrected 07-III-2016. Accepted 06-IV-2016.

\begin{abstract}
The seed dispersal process is a crucial stage in plant regeneration and maintenance of forest biological diversity. While the number of removed seeds is quantitative, the distance to which a seed is removed from its origin is qualitative, because it affects the probability that a seed will germinate and recruit to the next life stage. However, the creation of forest margins can negatively affect the seed dispersal process, especially for largediaspore plant species. In this study, the diaspore removal and dispersal distance of Caryocar coriaceum, a tree with large diaspores that is in danger of extinction, were analyzed. The study was conducted for two consecutive years in a protected forest in Northeastern Brazil. Each year, 1200 diaspores with a nylon wire and a satin tape yellow were used and equally distributed in 120 experimental stations established on the forest margin and in the interior. During the first year of the study, no differences in diaspore removal and dispersal distance were found among the investigated environments. However, for the second year of the study, the number of removed diaspores differed significantly; nevertheless, the dispersal distance was not different between the forest margin and the interior. The low diaspore removal percentages suggest that species recruitment may be compromised because the diaspore accumulation close to the relatives enables higher fungi and insect attack. In addition, most of the few removed diaspores were found at short distances from their sources (up to $5 \mathrm{~m}$ ), which can lead to low genetic variability. Virtually no diaspore was found buried by hoarding rodents, and no diaspore was found preyed upon by these animals. Evidence found in this study suggests the local loss of species dispersers, which can compromise the maintenance of forest biological diversity. Rev. Biol. Trop. 64 (3): 1117-1127. Epub 2016 September 01.
\end{abstract}

Key words: protected forests, biodiversity conservation, density dependent mortality, disperser loss, non-timber forest product.

Plant dispersion can be defined as seed removal from the plant origin, and the dynamics provide new habitats through colonization and maintenance of forest biological diversity (Wang \& Smith, 2002). When removal is mediated by vertebrates, the distance that the seeds reach in relation to the mother plant can result in potential advantages, such as decreased predation, which influences the spatial structure of the plant population and long-term viability (Janzen, 1970; Wang \& Smith, 2002). Animal dispersion effectiveness has important quantitative and qualitative components for plant reproductive success. While the numerical analysis of removed seeds is quantitative, the analysis of the distance to which a seed is removed from its origin is qualitative, because it determines the likelihood a seed has of 
germinating and recruiting for the next stage of life (Schupp, 1993). However, human activities such as seeds extraction and hunting animal dispersers, can limit the seed dispersal process dynamics by breaking this interaction between the plant and animal dispersers with diverse consequences for both (Forget \& Jansen, 2007; Muler et al., 2014).

In Northeastern Brazil, among the extraction target species Caryocar coriaceum Wittm. (Caryocaraceae) stands out due to the food and medicinal value of the diaspores. C. coriaceum extraction is an important employment and income source for many people living around protected areas such as the Araripe-Apodi National Forest (FLONA Araripe), nevertheless, is a species that is "at risk" of extinction (Medeiros \& Amorim, 2015). Historically, in times of good harvest, whole families camp on the margin of this protected area to facilitate diaspore collection, transportation and beneficiation (Sousa Júnior, Albuquerque, \& Peroni, 2013; Cavalcanti, Ramos, Araújo, \& Albuquerque, 2015; Silva, Gomes, \& Albuquerque, 2015).

C. coriaceum diaspores are large and potentially dispersed by hoarding rodents, such as agouti (Dasyprocta spp.), and this vertebrate has already been named one of the main dispersers of another species of the same genus (Caryocar brasiliense Camb.) (Gribel, 1986). In addition to this animal, it was observed that beetles (Coleoptera: Scarabaeidae) could be related to $C$. brasiliense in that they bury diaspores (Vaz-de-Melo, Louzada, \& Schoereder, 1998).

Despite the agouti behaving as a seed predator (it breaks the endocarp and consumes the endosperm, which prevents the embryo from germinating), seeds that are buried and not consumed by the animal can germinate and enable population renewal (Forget, 1996; Jansen, Bongers, \& Hemerik, 2004). However, it is documented that this vertebrate is unfortunately one of the mammals that is hunted in some forests (Peres, 2000), including C. coriaceum occurrence zones (IBAMA, 2004; Melo, Silva, Souto, Alves, \& Schiel, 2014).
Generally, people access forests to conduct several activities, such as diaspore extraction and hunting, which is facilitated by the occurrence of roads (Peres \& Lake, 2003). Such roads generate forest margins (called linear margins), which besides facilitating human access, it can cause several fragmentation impacts within the forest (Goosem, 2007). Eventhough, the presence of linear margins is common in multiple forests, the knowledge of the impact of these margins on diaspore removal is still very scarce, and is focused on effects from margins formed by more extensive matrices. In this context, several studies have shown that seed removal and dispersal distance are smaller in the margin than in the forest, especially for large-seed plant species, and probably due to the local loss of animal dispersers, which are more vulnerable to fragmentation (Cramer, Mesquita, \& Williamson, 2007; Galetti et al., 2013; Magrach, Laurance, Larrinaga, \& Santamaria, 2014). Thus, the present study aimed to analyze C. coriaceum diaspore removal and dispersal distance for two consecutive years and considered individuals located on the margin and within a protected forest in Northeastern Brazil. The guiding question of this study was as follows: does $C$. coriaceum diaspore removal on the margin differ from that in the forest interior? To answer this question, it was hypothesized that diaspore removal differs between the margin and the forest interior. We expected to find higher frequency and reach of diaspores removal in the interior than in the margin of the forest.

\section{MATERIAL AND METHODS}

Study area: The study was conducted in the Araripe-Apodi National Forest (FLONA Araripe), which is a sustainable use protected area (created by Federal Decree-Law n ${ }^{\circ} 9226$, May 2nd 1946) located between the following geographical coordinates: $7^{\circ} 11^{\prime} 42^{\prime \prime}-7^{\circ} 28^{\prime} 38^{\prime \prime}$

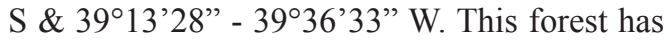
an area of approximately $39000 \mathrm{ha}$, is on the Chapada do Araripe, and covers the municipalities of Crato, Barbalha, Jardim and Santana 
do Cariri, which are all located in the state of Ceará, Northeastern Brazil (Ribeiro-Silva, Medeiros, Gomes, Seixas, \& Silva, 2012).

FLONA Araripe is under the influence of a hot and humid tropical climate with the highest rainfall from January to May. The mean annual temperature is $25^{\circ} \mathrm{C}$, and the mean annual rainfall is $1090 \mathrm{~mm}$. It has a tabular relief with altitudes ranging between 760 and $960 \mathrm{~m}$. It also has the predominant presence of Haplustox and Haplortox soils that are at a good depth and well drained (IBAMA, 2004; IPECE, 2014).

FLONA Araripe fauna is represented by species of several groups. Regarding mammals, six orders were recorded, including 15 families and 41 species, with the Rodentia order represented by the largest number of species $(\mathrm{n}=17)$, followed by the orders Carnivora $(\mathrm{n}=11)$, Pilosa $(\mathrm{n}=5)$, Artiodactyla $(\mathrm{n}=4)$, Marsupialia $(\mathrm{n}=3)$ and Primates $(\mathrm{n}=1)$ (Cruz \& Campello, 1998). The vegetation consists of a Semi-Deciduous Forest, Cerrado, Cerradão and Carrasco areas and houses a total of 188 angiosperm species, with the families Rubiaceae and Fabaceae being the richest (Ribeiro-Silva et al., 2012).

Many people from communities surrounding FLONA Araripe directly or indirectly depend on plant products offered by this forest such as Stryphnodendron rotundifolium Mart., Dimorphandra gardneriana Tullasne., Himatanthus drasticus Plumel., Hancornia speciosa Gomes., Parkia platycephala Benth., and especially Caryocar coriaceum Wittm. (IBAMA, 2004; Sousa Júnior et al., 2013; Feitosa, Albuquerque, \& Monteiro, 2014; Silva et al., 2015).

Certain other activities developed at FLONA Araripe generate problems and conflicts in addition to counteracting the current environmental legislation, such as illegal hunting, which is favored by the existence of roads cutting into the forest (IBAMA, 2004). The deer (Mazama gouazoubira), the agouti (Dasyprocta prymnolopha) and the nine-banded armadillo (Dasypus novemcinctus) are the most hunted mammals in the region and are primarily used for food purposes (Melo et al., 2014).
The completion of this FLONA Araripe study had the approval (No. 38234-1) of the Biodiversity Authorization and Information System (SISBIO) and the Chico Mendes Institute for Biodiversity Conservation (ICMBio), which is responsible for managing the protected area.

Studied species: C. coriaceum (known as pequi) is a heliophile tree that prefers high-light environments and can reach $2 \mathrm{~m}$ in diameter and $15 \mathrm{~m}$ in height. It occurs mainly in Cerrado vegetation, especially in the Chapada do Araripe region, and has primary barochoric and secondary zoochorous dispersion. Fruit flowering, fruiting and ripening occurs from November to April. C. coriaceum fruits are drupes with up to four bulky seeds and are wrapped in a woody endocarp with thin spines and a whitish-yellow pulp. The peak season occurs between January and March, which are full rainy season months when the species undergoes intense extraction (Braga, 1976; Costa, Araújo, \& Lima-Verde, 2004). The fruits are collected when they are ripe and fall to the ground. At this time, they are ready to have their pulp eaten or traded, and are sold in natura or in the form of oil, which is obtained after beneficiation. However, some collectors, when they do not find fallen fruit, come to collect them in the still immature state and collect fruits by shaking the branches or using sticks (Sousa Júnior et al., 2013; Silva et al., 2015).

In some forests, agouti is regarded as an essential disperser of several kinds of large seeds (Forget, 1996; Donatti, Guimarães Jr., \& Galetti, 2009; Tuck Haugaasen, Haugaasen, Peres, Gribel, \& Wegge, 2010). As observed for C. brasiliense, C. coriaceum seeds, due to their large size, can also be dispersed by the agouti, which is a medium-sized hoarding rodent (Gribel, 1986). Besides the agouti, other animals, such as beetles (Coleoptera: Scarabaeidae), known in Brazil as the "dung beetle", can be related to $C$. brasiliense and bury the mature fruits (Vaz-de-Melo et al., 1998). The burial standard of these beetles is quite characteristic and is quite different from the pattern 
found for seeds buried by agoutis. While "dung beetles" leave soil remains around deep holes (Hanski \& Cambefort, 1991), agoutis cap the hole, which is shallow, and they also often cover the area with leaves or buds (Dubost, 1988; Forget, 1996).

Diaspore removal and dispersal distance: Diaspore removal and dispersal distance monitoring was conducted for two consecutive years (2013 and 2014) during the local harvest period (between the beginning of February and end of March), due to natural availability of diaspores. In 2013, FLONA Araripe had a low production of pequi, a probable result of the drought that occurred in the region at this time. The monthly cumulative rainfall between late 2012 and early 2013, which is the diaspore development period, was below the historical mean of the last 30 years (Fig. 1). In 2014, diaspore production was visibly abundant, extending the harvest to the end of May.

To assess $C$. coriaceum diaspore removal and dispersal distance, three Cerrado areas were selected $\left(7^{\circ} 20^{\prime} 26.7^{\prime \prime} \mathrm{S}-39^{\circ} 28^{\prime} 12.9^{\prime \prime} \mathrm{W}\right.$; 7²4'32.3" S - 39²2'37.4" W; 7²0'26.6" $\mathrm{S}-39^{\circ} 28^{\prime} 46.7^{\prime \prime} \mathrm{W}$ ) with similar biotic and abiotic characteristics, and they were within approximately 10 to $50 \mathrm{~km}$ of one another. The three areas are separated by an unpaved road, which is approximately $10 \mathrm{~m}$ wide. The sites on the margins of the road are more open with and without grass cover clearing and are more frequented by $C$. coriaceum extractives in comparison to more internalized forest sites. The internalized forest sites are more closed with sparser midsize woody vegetation, are highly branched, and are more difficult to access but also frequented by extractives.

In each of the three areas, 40 C. coriaceum reproductive individuals were randomly selected (current fruiting or previously registered) with 20 located on the margin (up to a distance of $100 \mathrm{~m}$ from the margin into the forest) and 20 located in the interior $(600 \mathrm{~m}$ from the forest margin). The reproductive individuals had at least a $10 \mathrm{~m}$ distance between them to reduce one tree's interference on another during diaspore removal. The location of $C$. coriaceum individuals was based on Dodonov, Harper, \& Silva-Matos (2013), who observed forest margin effects, such as temperature, humidity and vegetation structure, at less than $100 \mathrm{~m}$ in Southeastern Brazil Cerrado fragments. It was also based on Laurance et al. (2002), who demonstrated in Amazon fragments that all forest margin effects identified by the Forest Fragments Biological Dynamics Project (PDBFF) penetrated up to $500 \mathrm{~m}$ in the fragments.

Under each selected individual canopy, ten morphologically similar $C$. coriaceum diaspores were placed directly on the soil and arranged in two rows (each with five diaspores) with a distance of $20 \mathrm{~cm}$ between rows and $10 \mathrm{~cm}$ between diaspores. Each ten diaspore group, which was arranged in two rows, was an experimental station totaling 1200 diaspores that were equally spread in 120 experimental

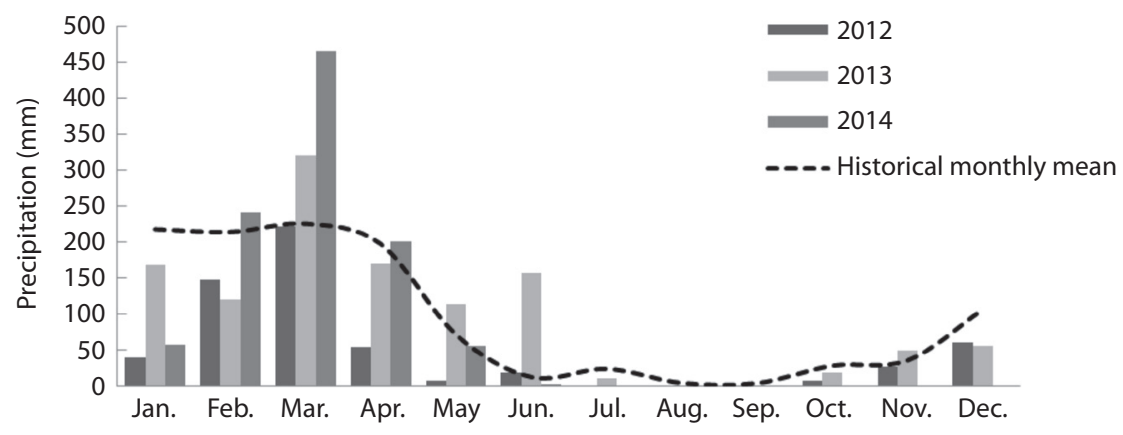

Fig. 1. Rainfall historical mean and monthly accumulation for 2012, 2013 and 2014 recorded by the Barbalha automatic station, Ceará, Brazil. Source: INMET (2014). 
stations with 60 on the forest margin and 60 on the forest interior in each study year. The entire circular area encompassing the diaspore rowing center up to a $1 \mathrm{~m}$ radius corresponded to an experimental station (Donatti et al., 2009). All diaspores used in the experiment were randomly collected in the forest.

Before rowing, the diaspores were marked sequentially as follows: 1) using an electric drill and a $3 \mathrm{~mm}$ drill bit, each diaspore was drilled; 2) through drilling, a $60 \mathrm{~cm}$ long nylon wire was introduced with a small two-hole button tied in one of the ends; and 3) at the other end of the nylon wire and to facilitate relocation, a yellow $10 \mathrm{~cm}$ long satin tape was tied containing information regarding the plotting site and the individual under which the diaspore was rowed. Treatments applied to the diaspores were made according to the methodologies adopted in other studies (Forget, 1990; Jorge \& Howe, 2009) to avoid interference with the results found here. The diaspores used in this study does not interest for collectors, since they were drilled and are not suitable for sale. However, the presence of collectors in the forest can not be ignored.

After all experimental stations were established (February 2013 and 2014), they were visited for eight straight weeks at the fruiting peak of two consecutive seasons. Such visits were always made on the same day, following the same places covered during installation of the experimental stations. Before the experimental assembly and at each weekly visit, all of the diaspores that were at a distance of 2 $\mathrm{m}$ from the experimental station centers were collected to minimize their influence on those used in the study (Donatti et al., 2009). During the eight weeks the diaspores were not replaced because of diaspores Attalea geraensis (Arecaceae) continued to be removed in the Cerrado of Southern Brazil, in a similar period (Almeida \& Galetti, 2007).

The diaspores were recorded as follows: (1) present in the stations - when they were still attached to the nylon wire and were found buried or on the soil in the experimental stations, and (2) removed from the stations - when they were not found (lost) or when they were found buried, above ground and attached to the nylon wire from the experimental stations (Donatti et al., 2009; Tuck Haugaasen et al., 2010).

According to the burial characteristics, the diaspores were classified as buried by "dung beetles" (Hanski \& Cambefort, 1991) or agoutis (Dubost, 1988; Forget, 1996). The dispersal distance of diaspores without vertebrate predation signals (partial or totally destroyed broken endocarps and consumed endosperm) was quantified from within $1 \mathrm{~m}$ of the experimental station center (Donatti et al., 2009).

Diaspore demand was found at up to a distance of $100 \mathrm{~m}$ from the experimental station center, and it was shown that hoarding rodents can remove large seeds to this distance (Jansen et al., 2004). The plant litter present in the search radius was spread to increase the chances of finding diaspores. The diaspore dispersal distance was measured in a straight line from the experimental station installation site center to the site where seeds were found using a fiberglass tape measuring $100 \mathrm{~m}$ in length. Once the removal and the distance achieved by diaspores were registered, they remained in place until the end of each study period.

At the end of each monitoring period, the total number of present and removed diaspores was added according to the forest margin or interior site location. The present and removed diaspore percentage and dispersal distance percentages achieved by diaspores were also calculated for the forest margin and interior. Diaspores removed were quantified using its absolute value and the differences in removal between the forest margin and the interior were analyzed using the one-sample chi-square test (adhesion) with equal expected proportions. To test whether there were differences in the mean dispersal distance between the forest margin and interior, a Mann-Whitney test was used. The normality of the mean data of dispersal distance was tested by the Shapiro-Wilk test $(p<0.05)$, which clarified that the data were not normally distributed. All of the analyses were conducted with the BioEstat 5.0 program (Ayres, Ayres Júnior, Ayres, \& Santos, 2007). 


\section{RESULTS}

In the first year of the study the number of removed diaspores did not differ significantly between study areas $\left(X^{2}=1.70, \mathrm{P}=0.19\right)$. The number of removed diaspores in the forest margin (50 diaspores) was similar to that recorded for the interior (65 diaspores). However, in the second year of the study the number of removed diaspores differed significantly $\left(X^{2}=\right.$ $7.01, \mathrm{P}<0.01)$ with 66 diaspores in the forest margin, and 38 diaspores in the interior. This means that forest margin does not directly affect in the number of removed diaspores.

Most removed diaspores were found on the soil, both on the forest margin and the interior, in the two years of the study (Table 1). Only in year II were six diaspores removed and buried by agoutis in the forest interior at distances of $2 \mathrm{~m}(\mathrm{n}=1), 3 \mathrm{~m}(\mathrm{n}=2), 5 \mathrm{~m}(\mathrm{n}=1), 10 \mathrm{~m}(\mathrm{n}=$ 1) and $15 \mathrm{~m}(\mathrm{n}=1)$ from the experimental station center.

In the two years of the study, buried diaspores were found at the experimental stations (Table 1). The hole formation observed at the experimental stations was characteristic of "dung beetles". Moreover, all of the diaspores found on the soil in the experimental stations, had been attacked by fungi or insects. All diaspores that have been found from experimental stations had signals of internal consumption of pulp, but have not had the endocarp broken. These signals are indications that these diaspores were manipulated by animals, probably rodents.

Despite the highest mean dispersal distance being recorded in the forest margin and in the second year of the study (Year I: margin= $2.77 \pm 0.26 \mathrm{~m}$, interior $=3.59 \pm 0.54 \mathrm{~m}$; Year II: margin $=4.55 \pm 1.32 \mathrm{~m}$, interior $=2.66 \pm 0.58$ $\mathrm{m})$, there were no differences in mean dispersal distance between the forest margin and the interior (Year I: $\mathrm{U}=6735.0, \mathrm{P}=0.92$; Year II: $\mathrm{U}=510.5, \mathrm{P}=0.35$ ).

In the first year of the study and at the forest margin, only one diaspore $(3.33 \%)$ reached the farthest dispersal distance registered for this site, which was $6 \mathrm{~m}$, whereas the highest dispersal distance achieved in the forest interior, also by one diaspore (2.12\%), was $22 \mathrm{~m}$. In the second year of the study and at the forest margin, only two diaspores $(4.76 \%)$ were removed at a maximum distance of $40 \mathrm{~m}$ from the experimental station, whereas in the forest interior, the highest distance achieved by a single diaspore $(3.57 \%$ ) was $15 \mathrm{~m}$ (Table 2$)$. However, in the two years of the study, both on the forest margin and the interior, most of the diaspores had been moved up to $5 \mathrm{~m}$ from the experimental stations (Year I: margin $=96.64$ $\%[\mathrm{n}=29]$ and interior $=82.94 \%[\mathrm{n}=39]$; Year II: margin $=88.07 \%[\mathrm{n}=37]$ and interior $=$ $92.84 \%[n=26])$.

TABLE 1

Caryocar coriaceum present and removed diaspore percentage and number over two years of study at the margin and in the interior of the Araripe-Apodi National Forest, Ceará, northeastern Brazil

\begin{tabular}{lcccc} 
& \multicolumn{2}{c}{ Year I } & Year II \\
& Margin & Interior & Margin & Interior \\
Diaspores present in the stations & & & & \\
$\quad$ & & & \\
$\quad$ Buried & $3.3(\mathrm{n}=20)$ & $2(\mathrm{n}=12)$ & $2.8(\mathrm{n}=17)$ & $0.8(\mathrm{n}=5)$ \\
On the soil & $88.3(\mathrm{n}=530)$ & $87.2(\mathrm{n}=523)$ & $86.2(\mathrm{n}=517)$ & $92.8(\mathrm{n}=557)$ \\
Total & $91.6(\mathrm{n}=550)$ & $89.2(\mathrm{n}=535)$ & $89(\mathrm{n}=534)$ & $93.6(\mathrm{n}=562)$ \\
$\begin{array}{l}\text { Diaspores removed from the stations } \\
\text { Not found }\end{array}$ & $3.3(\mathrm{n}=20)$ & $3(\mathrm{n}=18)$ & $4(\mathrm{n}=24)$ & $1.7(\mathrm{n}=10)$ \\
$\quad$ & - & - & - & $1(\mathrm{n}=6)$ \\
Buried & $5(\mathrm{n}=30)$ & $7.8(\mathrm{n}=47)$ & $7(\mathrm{n}=42)$ & $3.7(\mathrm{n}=22)$ \\
On the soil & $8.3(\mathrm{n}=50)$ & $10.8(\mathrm{n}=65)$ & $11(\mathrm{n}=66)$ & $6.4(\mathrm{n}=38)$ \\
\hline
\end{tabular}


TABLE 2

Caryocar coriaceum diaspore distance dispersal percentage in two years of the study at the margin and in the interior of Araripe-Apodi National Forest, Ceará, Northeastern Brazil

\begin{tabular}{|c|c|c|c|c|}
\hline \multirow{2}{*}{ Dispersal distance (m) } & \multicolumn{2}{|c|}{ Year I } & \multicolumn{2}{|c|}{ Year II } \\
\hline & Margin & Interior & Margin & Interior \\
\hline 1.5 & $33.33(n=10)$ & $40.42(n=19)$ & $42.85(n=18)$ & $53.57(n=15)$ \\
\hline 2 & $13.33(\mathrm{n}=4)$ & $10.63(\mathrm{n}=5)$ & $16.66(n=7)$ & $14.28(\mathrm{n}=4)$ \\
\hline 2.5 & $6.66(n=2)$ & $4.25(n=2)$ & $11.9(n=5)$ & - \\
\hline 3 & $16.66(n=5)$ & $10.63(\mathrm{n}=5)$ & $4.76(n=2)$ & $14.28(n=4)$ \\
\hline 3.5 & $3.33(\mathrm{n}=1)$ & - & - & $3.57(\mathrm{n}=1)$ \\
\hline 4 & $10(n=3)$ & $12.76(n=6)$ & $9.52(n=4)$ & - \\
\hline 4.5 & - & - & - & $3.57(\mathrm{n}=1)$ \\
\hline 5 & $13.33(\mathrm{n}=4)$ & $4.25(\mathrm{n}=2)$ & $2.38(\mathrm{n}=1)$ & $3.57(\mathrm{n}=1)$ \\
\hline 6 & $3.33(\mathrm{n}=1)$ & - & - & - \\
\hline 7 & - & $2.12(\mathrm{n}=1)$ & $2.38(\mathrm{n}=1)$ & - \\
\hline 8 & - & $6.38(n=3)$ & - & - \\
\hline 9 & - & $2.12(\mathrm{n}=1)$ & - & - \\
\hline 10 & - & $4.25(n=2)$ & - & $3.57(\mathrm{n}=1)$ \\
\hline 15 & - & - & $4.76(n=2)$ & $3.57(\mathrm{n}=1)$ \\
\hline 22 & - & $2.12(n=1)$ & - & - \\
\hline 40 & - & - & $4.76(n=2)$ & - \\
\hline
\end{tabular}

\section{DISCUSSION}

Contrary to what was hypothesized, significant differences were not found in diaspore removal between the forest margin and interior in the first year of the study. In the second year of study, and different from what we predict, the removal of diaspores was higher in the forest margin. It has been shown that diaspore removal may even be higher in the forest margin than in the interior (Galletti, Alves-Costa, $\&$ Cazetta, 2003). However, this seems to occur for plant species of small seeds, for example, Prunus africana (Menke, Böhning-Gaese, \& Schleuning, 2012). However, seems that this would not apply to $C$. coriaceum, considering their natural occurrence in high-light environments; probably, its animal dispersers occur in the forest margin and interior. But, factors such as lower availability of diaspores because of drought or extractivism, can negatively affect animal dispersers and dispersal process (Tuck Haugaasen et al., 2010; Muler et al., 2014).

These study results were quite intriguing because both in the forest margin and the interior, this study's results revealed a low diaspore removal percentage (maximum $11 \%$ ). However, similar results were previously found by Donatti et al. (2009) using models, in which the Astrocaryum aculeatissimum large seed removal percentage was $16 \%$ within protected fragments of the Atlantic Forest in Southeastern Brazil. These authors concluded that the lower seed removal in these sites took place due to the local loss of animal dispersers, which collapsed the A. aculeatissimum seed dispersal. Faced with these revelations, these study results indicate the possibility that $C$. coriace$u m$ is locally losing its animal dispersers. This reinforces the need for efficient public actions and policies, so that appropriate measures are designed for animal disperser protection.

In addition to a lack of dispersal distance, differences in means between the forest margin and the interior, it was found that few diaspores were removed more than $5 \mathrm{~m}$ from the experimental stations. Considering that seed dispersal is a crucial stage in plant regeneration, the lack of removal from its origins can limit or severely reduce adult vicinity recruitment because seed or seedling accumulation close to 
relatives enables higher pathogen attack (fungi and insects), that is, higher density-dependent mortality (Janzen, 1970; Cordeiro, Ndangalasi, McEntee, \& Howe, 2009). Thus, the study findings suggest that $C$. coriaceum recruitment may be compromised by the lack of diaspore removal with the seeds being condemned to density-dependent mortality. In Tanzania, for example, it was shown that the clearest evidence for reduced recruitment of Leptonychia usambarensis was the lack of seed removal and subsequent seedling mortality close to the adults (Cordeiro et al., 2009). Moreover, seed removal at small distances can influence gene flow and intra- and inter-genetic structures of plant species (Nathan \& Muller-Landau, 2000). Thus, low genetic variability for $C$. brasiliense has been revealed and is likely due to reduced gene flow via seeds (Collevatti, Grattapaglia, \& Hay, 2003). In addition to conserving genetic variability, removal by animals from the mother plant can bring potential advantages for seeds such as decreased predator attack (Janzen, 1970; Forget, 1996).

It was noted that some diaspores were in natura buried in the experimental stations by "dung beetles" through the observed hole characteristics (Hanski \& Cambefort, 1991). This has also been observed in previous studies for C. brasiliense (Vaz-de-Melo et al., 1998) and Annona crassiflora (Golin, Santos-Filho, \& Pereira, 2011). However, the vast majority of the studies associate the "dung beetle" with seeds contained in the feces of other animal burials, especially of medium and large size. For example, Andresen (2001), in a central Amazon study, showed that Micropholis guyanensis seeds were only buried by these beetles when surrounded by at least $5 \mathrm{~g}$ of primate feces, and seeds that were not involved in feces were preyed on by rodents. When burying seeds, these beetles help protect the seed from predators and provide environmental improvements for germination by promoting soil fertilization and aeration (Nichols et al., 2008). However, this action does not seem to be efficient for $C$. coriaceum because seed germination buried under tree canopies probably would lead to significant seedling mortality and reduce their established success likelihood.

Virtually no diaspores were buried by agoutis, and no diaspores were preyed on by these animals in both on the forest margin and the interior. Even if the diaspores that were not found were buried or preyed on by these vertebrates, the percentage would be lower (maximum $4 \%$ ). In contrast to what was noted, studies have emphasized that in periods of high food availability (as was observed in the second year of this study), the biggest trend is resource hoarding in opposition to scarcity periods (as noted in the first research year), where agouti seed predation is higher, for example, for Carapa procera (Forget, 1996) and Bertholletia excelsa (Tuck Haugaasen et al., 2010).

Although agouti abundance was not studied (and these are potential pequi dispersers), these findings were interpreted as indirect evidence of local loss of these animals because it was already shown that they are widely hunted in the FLONA Araripe region (IBAMA, 2004; Melo et al., 2014). In addition, for $C$. procera it was shown that hunting of the main animal dispersers has compromised the seed dispersal process and establishment of this species in Guyana (Forget \& Jansen, 2007). Moreover, seed dispersal limitation due to a lack of seed removal from its origins is an indication that seed dispersers are scarce or absent (Wang, Sork, Leong, \& Smith, 2007). In addition, fragmentation and habitat loss has caused the loss of the few agents available for the dispersal of large-seed (Cramer et al., 2007). Therefore, for large-seed plant species, the dispersal ecosystem service can be interrupted due to the disperser decrease caused by the forest fragmentation effect (Cramer et al., 2007; Menke et al., 2012; Galetti et al., 2013).

Finally, these study results showed that the forest margin has not directly influenced pequi dispersion, but the low diaspore removal percentages and short distance of dispersal has drawn attention. This suggests that the plantdisperser animal interaction may be reduced in the studied region, likely due to disperser reduction to the point where they cannot 
significantly interact, which has been called functional ecological extinction (Galetti et al., 2013). It is possible that disperser reduction was caused by FLONA Araripe hunting activities, which have direct ecological dispersal process impacts and reduce the number of removed seeds and dispersal distance (Wang et al., 2007; Markl et al., 2012; Aliaga-Rossel \& Fragoso, 2015). Thus, we stress the importance of future studies on anthropogenic influence (e.g. hunting) on seed dispersal. We emphasize yet the lack of long time series of study that relates rain distribution, fruit production, and its success based on the distance from the mother plant.

\section{ACKNOWLEDGMENTS}

The authors are grateful to the Higher Education Personnel Improvement Coordination (CAPES) by the PhD scholarship granted to G. C. Santos and financial support (process 23038.008230/2010-75). The authors would also like to thank the Foundation for Science and Technology of the State of Pernambuco (FACEPE) for financial support (APQ-process 1264-2.05/10), the National Council for Scientific and Technological Development (CNPq) for the research productivity scholarship awarded to E. L. Araújo and U. P. Albuquerque, and the colleagues of the Laboratory of Ecology and Evolution of Social-Ecological Systems (LEA).

\section{RESUMEN}

Remoción y distancia de dispersión de las diásporas de Caryocar coriaceum (Caryocaraceae) en el margen e interior de un área de Cerrado, Noreste de Brasil. El proceso de dispersión de semillas es una etapa crucial en la regeneración de las plantas y el mantenimiento de la diversidad biológica de los bosques. Mientras que el número de semillas removidas es cuantitativo, la distancia a la que se elimina una semilla desde su origen es cualitativa, porque afecta la probabilidad de que una semilla germine y sea reclutada para la próxima etapa del ciclo de vida. Sin embargo, la creación de márgenes de los bosques puede afectar negativamente el proceso de dispersión, especialmente para especies de plantas con diásporas grandes. En este estudio, analizamos la remoción diásporas y la distancia de dispersión de C. coriaceum, un árbol de diásporas grandes que está en peligro de extinción. El estudio se llevó a cabo durante dos años consecutivos en un bosque protegido en el Noreste de Brasil. Cada año, un total de 1 200 diásporas fueron igualmente distribuidas, con un hilo de nylon y una cinta amarilla de satén, en 120 estaciones experimentales establecidas en el margen y en el interior del bosque. En el primer año del estudio, no se encontraron diferencias en la remocíon de las diásporas y la distancia de dispersión entre los ambientes estudiados. Sin embargo, en el segundo año el número de diásporas retiradas difería significativamente, pero la distancia de dispersión no fue diferente entre el margen de bosques y el interior. El bajo porcentaje de remoción encontrado sugiere que el reclutamiento de especies puede estar comprometido, ya que la acumulación de diásporas próximas unas de otras es propicio para un mayor ataque de hongos e insectos. Además, la mayoría de las pocas diásporas removidas fueron encontradas a pequeñas distancias de su origen (hasta $5 \mathrm{~m}$ ), lo que puede generar una baja variabilidad genética. Prácticamente ninguna diáspora fue encontrada enterrada por los roedores recolectores y ninguna estaba depredada por estos animales. La evidencia encontrada en este estudio indica la pérdida local de dispersores de las especies, lo que puede poner en peligro el mantenimiento de la diversidad biológica de los bosques.

Palabras clave: bosques protegidos, conservación de la biodiversidad, mortalidad dependiente de la densidad, pérdida de dispersores, productos forestales no maderables.

\section{REFERENCES}

Aliaga-Rossel, E., \& Fragoso, J. M. (2015). Defaunation affects Astrocaryum gratum (Arecales: Arecaceae) seed survivorship in a sub-montane tropical forest. Revista de Biología Tropical, 63, 57-67.

Almeida, L. B., \& Galetti, M. (2007). Seed dispersal and spatial distribution of Attalea geraensis (Arecaceae) in two remnants of Cerrado in Southeastern Brazil. Acta Oecologica, 32, 180-187.

Andresen, E. (2001). Effects of dung presence, dung amount and secondary dispersal by dung beetles on the fate of Micropholis guyanensis (Sapotaceae) seeds in Central Amazonia. Journal of Tropical Ecology, 17, 61-78.

Ayres, M., Ayres Júnior, M., Ayres, D. L., \& Santos, A. S. (2007). BioEstat 5.0: aplicações estatísticas nas áreas das ciências biológicas e médicas. Belém: Sociedade Civil Mamirauá.

Braga, R. (1976). Plantas do Nordeste, especialmente do Ceará. Mossoró: Escola Superior de Agricultura de Mossoró. 
Cavalcanti, M. C. B. T., Ramos, M. A., Araújo, E. L., \& Albuquerque, U. P. (2015). Implications from the use of Non-timber Forest Products on the consumption of wood as a fuel source in human-dominated semiarid landscapes. Environmental Management, 56(2): 389-401.

Collevatti, R. G., Grattapaglia, D., \& Hay, J. D. (2003). Evidences for multiple maternal lineages of Caryocar brasiliense populations in the Brazilian cerrado based on the analysis of chloroplast DNA sequences and microsatellite haplotype variation. Molecular Ecology, 12, 105-115.

Cordeiro, N. J., Ndangalasi, H. J., McEntee, J. P., \& Howe, H. F. (2009). Disperser limitation and recruitment of an endemic African tree in a fragmented landscape. Ecology, 90, 1030-1041.

Costa, I. R., Araújo, F. S., \& Lima-Verde, L. W. (2004). Flora e aspectos auto-ecológicos de um encrave de cerrado na chapada do Araripe, Nordeste do Brasil. Acta Botanica Brasilica, 18, 759-770.

Cramer, J. M., Mesquita, R. C. G., \& Williamson, G. B. (2007). Forest fragmentation differentially affects seed dispersal of large and small-seeded tropical trees. Biological Conservation, 137, 415-423.

Cruz, M. A. O. M., \& Campello, M. L. C. B. (1998). Projeto Araripe: Recursos naturais e patrimônio - Biodiversidade / Fauna - Mastofauna terrestre.

Dodonov, P., Harper, K. E., \& Silva-Matos, D. M. (2013). The role of edge contrast and forest structure in edge influence: vegetation and microclimate at edges in the Brazilian cerrado. Plant Ecology, doi: 10.1007/ s11258-013-0256-0.

Donatti, C. I., Guimarães Jr., P. R., \& Galetti, M. (2009). Seed dispersal and predation in the endemic Atlantic rainforest palm Astrocaryum aculeatissimum across a gradient of seed disperser abundance. Ecological Research, 24, 1187-1195.

Dubost, G. (1988). Ecology and social life of the red acouchy, Myoprocta exilis; comparison with the orange-rumped agouti, Dasyprocta leporina. Journal of Zoology, 214, 107-123.

Feitosa, I. S., Albuquerque, U. P., \& Monteiro, J. M. (2014). Knowledge and extractivism of Stryphnodendron rotundifolium Mart. in a local community of the Brazilian Savanna, Northeastern Brazil. Journal of Ethnobiology and Ethnomedicine, doi:10.1186/1746-4269-10-64.

Forget, P. M. (1990). Seed dispersal of Vouacaporia americana by caviomorph rodents in French Guiana. Journal of Tropical Ecology, 6, 459-468.

Forget, P. M. (1996). Removal of seeds of Carapa procera (Meliaceae) by rodents and their fate in rainforest in French Guiana. Journal of Tropical Ecology, $12,751-761$.

Forget, P. M., \& Jansen, P. A. (2007). Hunting increases dispersal limitation in the tree Carapa procera, a nontimber forest product. Conservation Biology, $2,106-113$

Galetti, M., Alves-Costa, C. P., \& Cazetta, E. (2003). Effects of forest fragmentation, anthropogenic edges and fruit colour on the consumption of ornithocoric fruits. Biological Conservation, 111, 269-273.

Galetti, M., Guevara, R., Côrtes, M. C., Fadini, R., Von Matter, S., Leite, A. B., Labecca, F., Ribeiro, T., Carvalho, C. S., Collevatti, R. G., Pires, M. M., Guimarães Jr., P. R., Brancalion, P. H., Ribeiro, M. C., \& Jordano, P. (2013). Functional extinction of birds drives rapid evolutionary changes in seed size. Science, 340, 1086-1089.

Golin, V., Santos-Filho, M., \& Pereira, M. J. B. (2011). Dispersão e predação de sementes de araticum no Cerrado de Mato Grosso, Brasil. Ciência Rural, 41, 101-107.

Goosem, M. (2007). Fragmentation impacts caused by roads through rainforests. Current Science, 93, 1587-1595.

Gribel, R. (1986). Ecologia da polinização e da dispersão de Caryocar brasiliense Camb. (Caryocaraceae) na região do Distrito Federal (M Sc.Dissertation). Universidade de Brasília, Brasília.

Hanski, I., \& Cambefort, Y. (1991). Dung Beetle Ecology. Princeton: University Press, Princeton.

IBAMA, (2004). Instituto Brasileiro do Meio Ambiente e dos Recursos Naturais Renováveis. Plano de Manejo da Floresta Nacional do Araripe. Brasília.

INMET, (2014). Instituto Nacional de Meteorologia. Dados climáticos da estação automática de Barbalha-CE (1984-2014). Retrieved from http://www. inmet.gov.br

IPECE, (2014). Instituto de Pesquisa e Estratégia Econômica do Ceará. Perfil Básico Municipal. Barbalha-CE. Retrieved from http://www.ipece.ce.gov.br/ publicacoes/perfil basico/pbm2014/Barbalha.pdf (accessed 20.07.14)

Jansen, P. A., Bongers, F., \& Hemerik, L. (2004). Seed mass and mast seeding enhance dispersal by a Neotropical scatter-hoarding rodent. Ecological Monographs, 74, 569-589.

Janzen, D. H. (1970). Herbivores and the number of tree species in tropical forest. The American Naturalist, 104, 501-528.

Jorge, M. L. S. P., \& Howe, H. F. (2009). Can forest fragmentation disrupt a conditional mutualism? A case from central Amazon. Oecologia, 161, 709-718. 
Laurance, W. F., Lovejoy, T. E., Vasconcelos, H. L., Bruna, E. M., Didham, R. K., Stouffer, P. C., Gascon, C., Bierregaard, R. O., Laurance, S. G., \& Sampaio, E. (2002). Ecosystem decay of Amazonian forest fragments: A 22-year investigation. Conservation Biology, 16, 605-618.

Magrach, A., Laurance, W. F., Larrinaga, A. R., \& Santamaria, L. (2014). Meta-Analysis of the effects of forest fragmentation on interspecific interactions. Conservation Biology, 00, 1-7.

Markl, J. S., Schleuning, M., Forget, P. M., Jordano, P., Lambert, J. E., Traveset, A., Wright, S. J., \& Böhning-Gase, K. (2012). Meta-Analysis of the effects of human disturbance on seed dispersal by Animals. Conservation Biology, 26, 1072-1081.

Medeiros, H., \& Amorim, A. M. A. (2015). Caryocaraceae. In: Lista de Espécies da Flora do Brasil. Jardim Botânico do Rio de Janeiro. Retrieved from http:// floradobrasil.jbrj.gov.br (accessed 03.01.15).

Melo, R. S., Silva, O. C., Souto, A., Alves, R. M. N., \& Schiel, N. (2014). The role of mammals in local communities living in conservation areas in the Northeast of Brazil: an ethnozoological approach. Tropical Conservation Science, 7, 423-439.

Menke, S., Böhning-Gaese, K., \& Schleuning, M. (2012). Plant-frugivore networks are less specialized and more robust at forest-farmland edges than in the interior of a tropical forest. Oikos, 121, 1553-1566.

Muler, A. E., Rother, D. C., Brancalion, P. S., Naves, R. P., Rodrigues, R. R., \& Pizo, M. A. (2014). Can overharvesting of a non-timber-forest-product change the regeneration dynamics of a tropical rainforest? The case study of Euterpe edulis. Forest Ecology and Management, 324, 117-125.

Nathan, R., \& Muller-Landau, H. C. (2000). Spatial patterns of seed dispersal, their determinants and consequences for recruitment. Trends in Ecology \& Evolution, 15, 278-285.

Nichols, E., Spector, S., Louzada, J., Larsen, T., Amezquita, S., Favila, M. E., \& The Scarabaeinae Research Network (2008). Ecological functions and ecosystem services provided by Scarabaeinae dung beetles. Biological Conservation, 141, 1461-1474.
Peres, C. A. (2000). Effects of subsistence hunting on vertebrate community structure in Amazonian forests. Conservation Biology, 14, 240-253.

Peres, C. A., \& Lake, I. R. (2003). Extent of nontimber resource extraction in tropical forests: Accessibility to game vertebrates by hunters in the Amazon basin. Conservation Biology, 17, 521-535.

Ribeiro-Silva, S., Medeiros, M. B., Gomes, B. M., Seixas, E. N. C., \& Silva, M. A. P. (2012). Angiosperms from the Araripe National Forest, Ceará, Brazil. Check List, 8, 744-751.

Schupp, E. W. (1993). Quantity, quality and the effectiveness of seed dispersal by animals. Vegetatio, 108, 15-29.

Silva, R. R. V., Gomes, L. J., \& Albuquerque, U. P. (2015). Plant extractivism in light of game theory: a case study in northeastern Brazil. Journal of Ethnobiology and Ethnomedicine, doi:10.1186/1746-4269-11-6.

Sousa Júnior, J. R., Albuquerque, U. P., \& Peroni, N. (2013). Traditional knowledge and management of Caryocar coriaceum Wittm. (Pequi) in the Brazilian savanna, Northeastern Brazil. Economic Botany, 67, 225-233.

Tuck Haugaasen, J. M., Haugaasen, T., Peres, C. A., Gribel, R., \& Wegge, P. (2010). Seed dispersal of the Brazil nut tree (Bertholletia excelsa) by scatter-hoarding rodents in a central Amazonian forest. Journal of Tropical Ecology, 26, 251-262.

Vaz-De-Mello, F. Z., Louzada, J. N. C., \& Schoereder, J. H. (1998). New data and comments on Scarabaeidae (Coleoptera:Scarabaeoidea) associated with Attini (Hymenoptera:Formicidae). The Coleopterists Bulletin, 52, 209-216.

Wang, B. C., \& Smith, T. B. (2002). Closing the seed dispersal loop. Trends in Ecology \& Evolution, 17, 379-385.

Wang, B. C., Sork, V. L., Leong, M. T., \& Smith, T. B. (2007). Hunting of mammals reduces seed removal and dispersal of the afrotropical tree Antrocaryon klaineanum (Anacardiaceae). Biotropica, 39, 340-347. 
